\title{
PELATIHAN TANGGAP DARURAT BENCANA BAGI MAHASISWA KSR-PMI DALAM UPAYA MENINGKATKAN PERAN GENERASI MUDA DALAM PENANGGULANGAN BENCANA
}

\section{Emergency Disaster Response Training for KSR-PMI Students in Efforts To Improve the Role of Young Generations in Disaster Management}

\author{
Ida Ayu Eka Widiastuti ${ }^{1 *}$, Putu Aditya Wiguna ${ }^{2}$, Ida Bagus Alit ${ }^{3}$ \\ ${ }^{1}$ Bagian Fisiologi, Program Studi Pendidikan Dokter Universitas Mataram, ${ }^{2}$ Bagian Pediatri, \\ Program Studi Pendidikan Dokter Universitas Mataram, 3Jurusan Teknik Mesin Universitas \\ Mataram
}

Jlaan Pendidikan Nomor 37 Kota Mataram, Provinsi NTB

*Alamat korespondensi : ayueka@unram.ac.id

(Tanggal Submission: 9 November 2020, Tanggal Accepted: 28 Desember 2020)

\begin{abstract}
ABSTRAK
Indonesia adalah negara dengan potensi bencana cukup tinggi. Hampir di semua daerah pernah mengalami bencana, tidak terkecuali Provinsi NTB. Upaya penanggulangan bencana merupakan urusan bersama, pemerintah sebagai penanggung jawab dengan peran serta aktif masyarakat, termasuk unsur pemuda, terlebih para pemuda yang tergabung dalam organisasi yang bergerak dalam bidang kemanusiaan, seperti KSR-PMI. Agar dapat berpartisipasi aktif secara optimal, diperlukan pengetahuan dan keterampilan yang memadai. Salah satu metode yang dapat dilakukan adalah melalui pelatihan. Dari hasil wawancara, cukup banyak anggota KSR-PMI yang belum pernah mendapatkan pelatihan terkait penanggulangan bencana, sementara mereka pasti akan sangat diandalkan di lapangan apabila terjadi bencana. Pelatihan tanggap darurat bencana ini dirancang melalui tiga tahapan, yaitu tahap persiapan, pelaksanaan, dan evaluasi. Pelaksanaan berlangsung selama 3 hari, bertempat di aula PMI Provinsi NTB. Hari pertama dan kedua peserta pelatihan diberikan pengetahuan berupa teori-teori yang berhubungan dengan kondisi tanggap darurat bencana sedangkan pada hari ketiga para peserta mengikuti kegiatan simulasi bencana yang dilaksanakan di Pantai Gading, Mapak, Mataram. Peserta pelatihan berjumlah 26 orang, yang berasal dari 7 unit KSR-PMI se-Pulau Lombok. Evaluasi terhadap penyelenggaraan pelatihan dinilai dengan menggunakan kuesioner kepuasan dan capaian nilai yang diperoleh peserta. Melalui kegiatan pelatihan ini, pengetahuan dan pemahaman para peserta pelatihan tentang penanggulangan bencana dalam kondisi tanggap darurat meningkat $48,36 \%$. Dari hasil olah kuesioner disimpulkan performa para narasumber, baik $(80,8 \%)$, penyelenggaraan pelatihan, yang meliputi 3 aspek, yaitu prasarana/sarana, pengorganisasian penyelenggaraan, dan konsumsi pelatihan, baik $(85,83 \%)$. Pelatihan tanggap darurat bencana memberikan
\end{abstract}


peningkatan pengetahuan dan keterampilan peserta dalam penanggulangan kondisi tanggap darurat bencana.

Kata kunci: pelatihan, tanggap darurat bencana, KSR-PMI, pengetahuan dan keterampilan

\section{PENDAHULUAN}

Indonesia merupakan negara dengan potensi terjadi bencana yang cukup tinggi. Hal ini tidak lepas sebagai akibat dari kondisi geografis Indonesia. Indonesia merupakan tempat pertemuan 2 rangkaian gunung berapi aktif (Ring of Fire) dan terdapat puluhan patahan aktif di wilayah Indonesia. Di samping itu Indonesia pun rentan akan bencana gempa bumi akibat titik pertemuan antara lempeng Indo Australia dengan lempeng Samudera Pasifik. Dengan kondisi tersebut Indonesia ibarat 'bom waktu' yang sewaktu-waktu dapat meledak. Hal ini belum ditambah dengan bencana yang sifatnya akibat kerusakan lingkungan, seperti longsor, banjir, kekeringan dan sebagainya.

Di Provinsi NTB pernah terjadi beberapa kali bencan, dari gempa bumi, angin puting beliung, banjir maupun tanah longsor. Terjadinya berbagai bencana ini merupakan salah satu dampak dari kondisi atau letak geografis provinsi ini. Lima wilayah di Provinsi NTB, yaitu: Bima, Dompu, Sumbawa, Lombok Timur dan Lombok Barat, berpotensi untuk terjadi tsunami karena wilayah-wilayah itu berbatasan langsung dengan laut lepas. Tiga gunung yang tercatat masih aktif, Gunung Rinjani di Lombok Timur yang statusnya waspada, Gunung Sangeang di Kabupaten Bima yang kini statusnya waspada serta Gunung Tambora yang pernah meletus satu abad yang lalu dan menyebabkan perubahan musim di Eropa.

Bencana alam merupakan peristiwa
luar biasa yang dapat menimbulkan
penderitaan luar biasa bagi yang

mengalaminya, bahkan bencana alam tertentu menimbulkan banyak korban cedera maupun meninggal dunia. Dalam Undang-undang No. 24 Tahun 2007 tentang penanggulangan bencana telah disebutkan bahwa penanggulangan bencana merupakan urusan bersama, dalam hal ini pemerintah sebagai penanggung jawab dengan peran serta aktif masyarakat dan lembaga usaha. Salah satu program yang ditetapkan adalah pendidikan dan latihan dalam hal penanggulangan bencana dalam rangka mencetak tenaga-tenaga yang profesional di bidang penanggulangan bencana.

Korps Sukarela (KSR)-PMI adalah organisasi yang netral dan independen yang melakukan kegiatannya demi kemanusiaan dan secara sukarela. Pengetahuan dan keterampilan yang memadai menjadi suatu kewajiban yang mutlak harus dikuasai oleh anggota KSR-PMI dalam menjalankan fungsi dan perannya di lapangan ketika terjadi suatu bencana. Dalam upaya meningkatkan pengetahuan dan keterampilan para anggota KSR-PMI, khususnya KSR-PMI di lingkungan perguruan tinggi, sebagai pemuda, bagian dari masyarakat yang memiliki hak dan kewajiban berpartisipasi dalam memberikan bantuan saat terjadi bencana maka kegiatan pelatihan tanggap darurat bencana sangatlah diperlukan.

\section{METODE KEGIATAN}

Kegiatan pelatihan tanggap darurat bencana ini dilakukan melalui 3 tahapan, yaitu (1) persiapan, (2) pelaksanaan dan (3) evaluasi. Pada tahap persiapan tim menghubungi organisasi/lembaga yang terkait untuk mencari narasumber yang memiliki kompetensi sesuai dengan target luaran yang diharapkan dari 
pelatihan, mempersiapkan modul/bahan dan media, menyusun jadual pelatihan, menentukan lokasi, baik untuk pelatihan dalam ruangan maupun simulasi lapangan, waktu dan peserta pelatihan serta persiapan administrasi. Pelaksanaan kegiatan dibagi dalam 2 tahap, yaitu penyampaian materi yang bersifat teoritis selama 2 hari dan pada hari ketiga kegiatan simulasi bencana di Pantai Gading, Mapak. Pada tahap evaluasi dilakukan penilaian terhadap beberapa komponen, yaitu: (a) peserta, dari perbandingan nilai pretest dan posttest untuk mengukur pengetahuan peserta pelatihan (menilai aspek kognitif), (b) penilaian terhadap narasumber/fasilitator, dengan menggunakan kuesioner, dan (c) penilaian terhadap penyelenggaraan pelatihan, meliputi proses belajar mengajar, sarana, prasarana serta aspek pendukung lain selama pelatihan, dengan kuesioner.

Peserta pelatihan adalah anggota organisasi KSR-PMI se-Pulau Lombok, dengan kriteria: (1) pernah mengikuti pendidikan dasar KSR-PMI, (2) memiliki motivasi yang besar untuk menjadi relawan bencana, dan (3) Bersedia mengikuti pelatihan secara penuh, dari awal sampai akhir kegiatan. Narasumber pelatihan berasal dari PMI, yang telah memiliki sertifikat nasional dan relawan PMI yang memiliki pengalaman di daerah bencana.

\section{HASIL DAN PEMBAHASAN}

Kegiatan pelatihan Tanggap Darurat Bencana dilaksanakan pada tanggal 6-8 Juni 2015. Para peserta pelatihan yang berasal dari 7 unit KSR-PMI, yaitu: KSR-PMI Universitas Mataram, KSR-PMI Institut Agama Islam Negeri Mataram, KSR-PMI Universitas Muhammadiyah Mataram, KSR-PMI STMIK Mataram, KSR-PMI Anjani, NW Lombok Timur, KSR-PMI Pringgarata Lombok Timur dan KSR-PMI Praya, Lombok Tengah, yang seluruhnya berjumlah 26 orang, diinapkan di mess PMI Daerah NTB. Kegiatan hari pertama dan kedua adalah penyampaian materi oleh para narasumber. Pada hari ketiga kegiatan berupa simulasi bencana yang mengambil tempat di Pantai Gading, Mapak, Mataram. Para peserta dihadapkan pada skenario situasi bencana, yaitu tsunami. Mereka melakukan peran mereka sebagai relawan dalam melaksanakan langkah-langkah tanggap darurat, yang meliputi kesiapsiagaan individu, koordinasi penanggulangan bencana, assessment (penilaian keadaan), rencana operasi, distribusi bantuan serta monitoring dan evaluasi.

Target yang diharapkan dapat dicapai melalui kegiatan ini adalah meningkatnya pengetahuan para anggota KSR-PMI sebagai sebuah organisasi relawan yang bergerak di bidang kemanusiaan tentang penanggulangan bencana, khususnya dalam kondisi tanggap darurat bencana serta meningkatnya keterampilan para anggota KSR-PMI dalam memberikan bantuan dan pertolongan bagi para korban bencana dalam berbagai kondisi. Sebelum mengikuti pelatihan ini para peserta telah mendapatkan pengetahuan tentang tanggap darurat bencana namun hanya sebatas pengetahuan tanpa bekal keterampilan yang memadai yang sangat dibutuhkan bagi anggota KSR-PMI dalam menjalankan peran mereka sebagai seorang relawan apabila terjadi suatu bencana. Melalui kegiatan pelatihan ini, para peserta tidak hanya dibekali dengan pengetahuan, namun juga diberikan keterampilan mengenai penanggulangan bencana. Seperti diketahui daerah Provinsi Nusa Tenggara Barat termasuk daerah dengan potensi bencana yang cukup besar, terutama gempa dan gunung meletus.

Keberhasilan dari pelaksanaan pelatihan tanggap darurat bencana bagi anggota KSR-PMI ini utamanya diukur dari peningkatan/perbaikan nilai posttest 
dibandingkan dengan nilai pretest. Hasil yang diperoleh adalah terjadi peningkatan nilai sebesar 48,36\%. Dengan meningkatnya capaian nilai yang diperoleh maka dapat disimpulkan jika para peserta pelatihan memiliki pengetahuan dan pemahaman yang lebih baik tentang penatalaksanaan pada kondisi tanggap darurat bencana setelah mengikuti pelatihan dibandingkan dengan sebelum mendapatkan pelatihan.

Penilaian peserta pelatihan terhadap materi yang diberikan dalam pelatihan ini yang keseluruhannya berjumlah 11 materi menunjukkan hasil yang baik, yaitu sebesar $80,72 \%$. Sebagian besar peserta berpendapat bahwa materi yang diperoleh selama pelatihan bermanfaat bagi mereka. Materi yang diberikan terdiri dari: kepalangmerahan, pengantar manajemen bencana, protap tanggap darurat bencana, assessment, standar SPHERE, air dan sanitasi, struktur operasional, evakuasi korban bencana, relief distribusi, dapur umum dan simulasi lapangan.

Penilaian peserta terhadap performa dari para narasumber dinilai berdasarkan hasil kuesioner yang diisi oleh peserta setelah selesai kegiatan pelatihan. Hasil yang diperoleh menunjukkan bahwa rata-rata kemampuan para narasumber dalam menyampaikan materi pelatihan adalah baik (80,8\%). Hal ini dapat dilihat dari hasil kuesioner tentang narasumber, yang sebagian besar peserta memilih 4 (sangat memuaskan) dan sebagian kecil memilih 3 (cukup memuaskan), 2 (kurang memuaskan) ataupun 1 (tidak memuaskan). Narasumber yang dilibatkan dalam pelatihan ini adalah para relawan yang tergabung dalam PMI Daerah Nusa Tenggara Barat, yang telah memiliki sertifikat sebagai pelatih.

Penilaian peserta terhadap penyelenggaraan pelatihan, meliputi: proses belajar mengajar, sarana, prasarana serta aspek pendukung lain selama pelatihan. Sama halnya dengan penilaian terhadap performa narasumber, penilaian terhadap penyelenggaraan pelatihan didasarkan pada hasil kuesioner yang diisi oleh peserta pelatihan. Hasil yang diperoleh menunjukkan bahwa rata-rata penilaian peserta pelatihan terhadap penyelenggaraan pelatihan adalah baik $(89,2 \%)$, yang terdiri dari 3 komponen penilaian, yaitu pra sarana dan sarana $(88,33 \%)$, pengorganisasian penyelenggaraan $(85,83 \%)$ dan penilaian terhadap konsumsi (93,33\%). Sebagai resume dari evaluasi/umpan balik penyelenggaran pelatihan disajikan dalam Tabel 1 berikut ini.

Tabel 1. Resume Kuesioner Umpan Balik Penyelenggaraan kegiatan Pelatihan Tanggap Darurat Bencana KSR-PMI

\begin{tabular}{ccc}
\hline No & Komponen Penilaian & Nilai (\%) \\
\hline 1 & Materi & 80,72 \\
2 & Pemateri & 80,80 \\
3 & Pra sarana dan sarana & 88,33 \\
& Pengorganisasian & 85,83 \\
4 & penyelenggaraan pelatihan & \\
5 & Konsumsi pelatihan & 93,33 \\
\hline
\end{tabular}




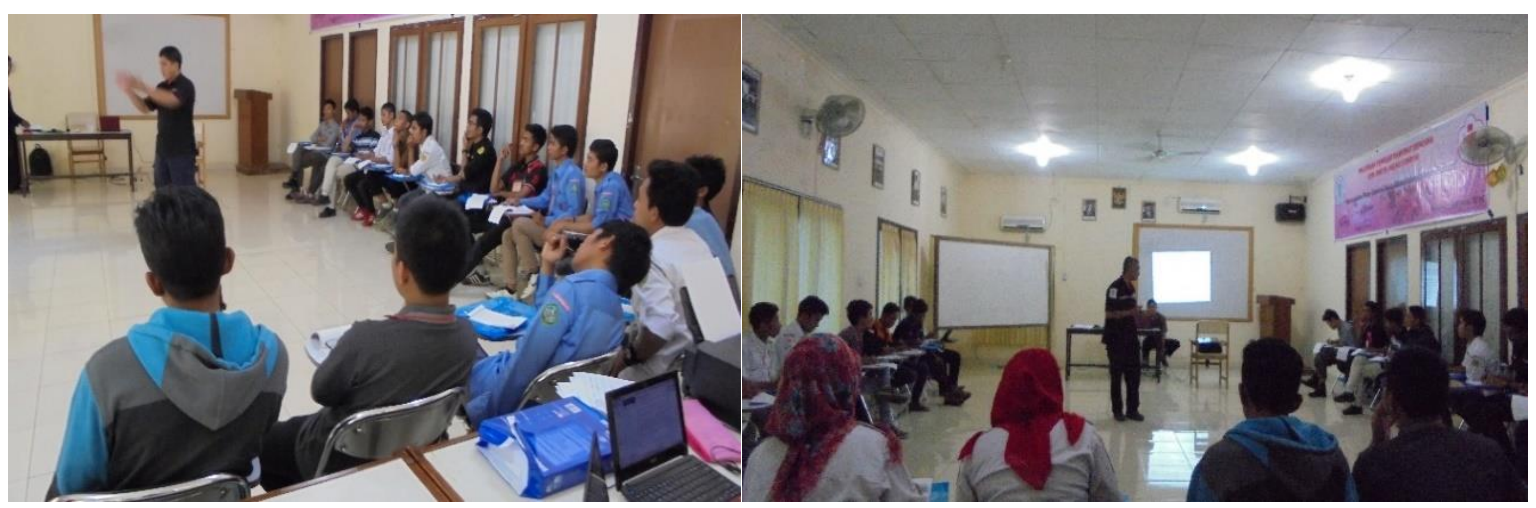

Gambar 1 Penyampaian Materi Pelatihan

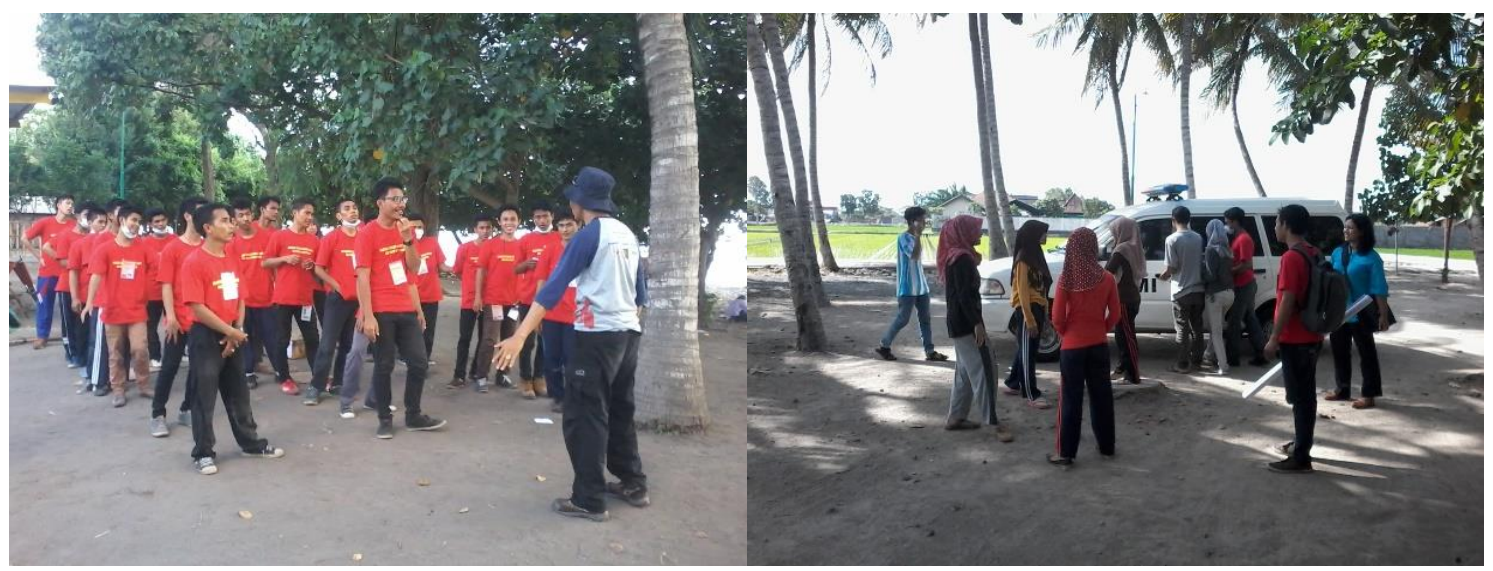

Gambar 2. Kegiatan di Pantai Gading Mapak

\section{SIMPULAN DAN SARAN}

Dari

kegiatan

pelatihan

penanggulangan tanggap darurat bencana ini dapat disimpulkan beberapa hal, yaitu: (1) pengetahuan dan pemahaman para peserta pelatihan tentang penanggulangan bencana, khususnya dalam kondisi tanggap darurat bencana meningkat $48,36 \%$, (2) penilaian terhadap performa para narasumber adalah baik $(80,8 \%)$,dan (3) penilaian terhadap penyelenggaraan pelatihan, yang meliputi 3 aspek, yaitu pra sarana/sarana, pengorganisasian penyelenggaraan dan konsumsi pelatihan adalah baik $(85,83 \%)$.

Sarana yang dapat kami sampaikan adalah: (1) dilaksanakan pelatihan serupa dengan melibatkan lebih banyak peserta, (2) kegiatan serupa dapat dilaksanakan dengan melibatkan lebih banyak pihak terkait sehingga dapat lebih terintegrasi dan lebih bermanfaat, (3) perlunya persiapan yang lebih matang terutama dalam kegiatan simulasi lapangan sehingga mampu menyediakan setting yang lebih representatif, (4) melaksanakan kegiatan serupa dengan kegiatan simulasi yang lebih beragam (variatif), dan (5) dilaksanakan tindak lanjut kegiatan, misalnya dalam bentuk 'transfer' pengetahuan dan keterampilan kepada siswa-siswa SMP dan SMA, khususnya yang tergabung dalam ekstrakurikuler Palang Merah Remaja

\section{UCAPAN TERIMA KASIH}

Penulis mengucapakan terima kasih kepada pihak PMI Daerah NTB atas dukungannya sehingga kegiatan pengabdian ini dapat terselenggara dengan baik. 


\section{DAFTAR PUSTAKA}

Azila, NN, 2013. Bencana alam di Indonesia 10 tahun terakhir. [online] Jakarta: Available at: https://www.academia.edu/4066595 [Accessed 12 April 2014].

Bappeda Provinsi NTB, 2013. NTB dalam angka. [online] Mataram: Available at: http://bappeda.ntbprov.go.id/wpcontent/uploads/2013/09/NTBdalamAn gka2011_01_babi-2011.pdf [Accessed 10 April 2014].

Direktorat Pengurangan Risiko Bencana Deputi Bidang Pencegahan dan Kesiapsiagaan, 2011. Sistem nasional penanggulangan bencana. [online] Jakarta: Available at: http://www.bnpb.go.id/uploads/pubs/5 2.pdf [Accessed 5 April 2014].

Suara NTB, 2010. Di NTB, 5 wilayah potensial diterjang tsunami. [online] Mataram: Available at: http://www.ntbprov.go.id/baca.php?ber ita $=110$ [Accessed 15 April 2014].

Utomo, T, 2012. Sistem nasional penanggulangan bencana. [online] Jakarta: Availabe at: http://www.mpbi.org/files/makalah/Sist em\%20Nasional\%20Penanggulangan\%2 OBencana.pdf [Accessed 5 April 2014].

Yani, A, 2010. Pengembangan pusat pelatihan dan simulasi kejadian bencana alam untuk pendidikan kebencanaan nasional. [online] Jakarta: Available at: http://file.upi.edu/Direktori/FPIPS/JUR._ PEND._GEOGRAFI/196708121997021. [Accessed 10 April 2014].

Yayasan Karina, 2010. Pelatihan penanggulangan gawat darurat. [online] Jakarta: Available at: http://www.karina.or.id/index.php/2012 -10-24-04-02-12/kilas-berita/112pelatihan-penanggulangan-gawatdarurat [Accessed 5 April 2014]. 